\title{
LA TRANSMISSIÓ MULTILINGÜE DE TEXTOS FILOSÒFICS A L'EDAT MITJANA
}

\author{
Alexander Fidora \\ ICREA / Universitat Autònoma de Barcelona \\ alexander.fidora@icrea.cat
}

Durant molt de temps, les traduccions d'obres filosòfiques del grec a l'àrab, malgrat la seva importància inqüestionable per al desenvolupament de la història de la filosofia, es consideraren fenòmens epigonals des d'un punt de vista filològic.

Els editors de les obres d'Aristòtil del segle xx poques vegades tingueren en compte la rica tradició àrab dels textos aristotèlics. Només darrerament, amb la creació de col-leccions com ara l'“Aristoteles Semitico-latinus" de la Koninklijke Nederlandse Akademie van Wetenschappen, s'ha parat més atenció a aquests testimonis, tot destacant-ne l'aportació, no només històrica, sinó també filològica.

En el cas d'Aristòtil, per exemple, moltes traduccions de les seves obres a l'àrab daten del segle Ix i x, quan els manuscrits grecs que se n'han conservat són, majoritàriament, del segle XII o més tardans. Això permet suposar que el traductor àrab, en més d'una ocasió, tenia al davant un exemplar grec que reflectia un estat del text més antic del que se'ns preserva en grec. Tot i la innegable intervenció del traductor, aquesta situació obre la possibilitat d'accedir a un estat més antic dels textos grecs, que en pot confirmar l'stemma i, fins i tot, pot ajudar a millorar-ne algunes lectures controvertides.

Aquesta via, que s'està explotant amb èxit en l'edició del "Corpus Medicorum Graecorum" de la Berlin-Brandenburgische Akademie der Wissenschaften, i en d'altres projectes, no està limitada a l'edició de textos grecs. De fet, els darrers anys, amb el nostre equip d'investigació hem pogut comprovar que també dóna resultats altament significatius en l'edició de textos llatins. Així, estudiant les traduccions hebrees de textos filosòfics medievals, hem reeditat algunes obres escolàstiques tot comparant-les amb les seves traduccions medievals a l'hebreu.

L'exemple més interessant és, sens dubte, la Quaestio de Unitate Universalis de Vicent Ferrer, que es conserva en un sol manuscrit llatí, del Dominikanerkonvent de Viena. Comparant el text llatí amb la traducció hebrea, produïda al segle $\mathrm{xv}$, hem pogut millorar considerablement la nostra comprensió de l'original. En dono només un exemple: 
Viena, Dominikanerkonvent 49/271, fol. 240r:

Cum dicitur quod universale est corruptibile sicut sua singularia, si multiplicentur ad multitudinem eorum, respondeo quod universale esse incorruptibile et sempiternum potest intelligi dupliciter. Uno modo per existentiam omni differentia temporis, si coexistat omni differentia temporis; et ut sic non est corruptibile nec coaeternum. Alio modo [...]

Vegem ara el text corregit a partir del manuscrit hebreu de Parma, Biblioteca Palatina, Parmense 2631:

Cum dicitur quod universale est corruptibile sicut sua singularia, si multiplicetur ad multitudinem eorum, respondeo quod universale esse incorruptibile et sempiternum potest intelligi dupliciter. Uno modo per existentiam omni differentia temporis, si coexistat omni differentia temporis; et ut sic non est incorruptibile nec coaeternum. Alio modo [...]

Però encara hi ha més, perquè en el cas de la Quaestio de Unitate Universalis, el text hebreu no només ajuda a millorar la lectura de l'original, sinó que n'ofereix un text molt més ampli. Cal constatar que el text llatí conservat correspon a una quarta part de la traducció hebrea. Així, abans d'oferir el text llatí que coneixem pel manuscrit de Viena, la versió hebrea tradueix tres apartats més, que només ens han arribat en hebreu. L'estructura dels dos textos es pot comparar en la següent taula:

\begin{tabular}{|c|l|}
\hline $\begin{array}{l}\text { Vicent Ferrer, Quaestio de Unitate Uni- } \\
\text { versalis, els paràgrafs corresponen a l'ed. } \\
\text { Fidora/Zonta }\end{array}$ & $\begin{array}{l}\text { Máamar Nikhbad Ba-Kolel, els paràgrafs } \\
\text { corresponen a l'ed. Fidora/Zonta }\end{array}$ \\
\hline$\varnothing$ & $\begin{array}{l}\text { Una “qüestió disputada" sobre si l'universal } \\
\text { existeix fora de l'ànima (\$ 2-30). Aquesta } \\
\text { qüestió inclou: }\end{array}$ \\
\hline$\varnothing$ & $\begin{array}{l}\text { Una definició explicativa de l'“universal } \\
\text { real" (\$ IO-I4). }\end{array}$ \\
\hline$\varnothing$ & $\begin{array}{l}\text { Una "qüestió disputada" sobre si l'universal } \\
\text { existeix en l'ànima (\$ 32-45). }\end{array}$ \\
\hline
\end{tabular}




\begin{tabular}{|c|c|}
\hline$\varnothing$ & $\begin{array}{l}\text { Una “qüestió disputada" sobre si l'universal } \\
\text { és idèntic amb els seus individus }(\$ 46-5 \mathrm{I}) \text {. }\end{array}$ \\
\hline $\begin{array}{l}\text { Una "qüestió disputada" sobre si la unitat } \\
\text { de l'universal és real (\$ } \$ \text { I-83). Aquesta } \\
\text { qüestió inclou: }\end{array}$ & $\begin{array}{l}\text { Una "qüestió disputada" sobre si la unitat } \\
\text { de l'universal és real ( } \$ \text { 8I-I3I). Aquesta } \\
\text { qüestió inclou entre d'altres: }\end{array}$ \\
\hline $\begin{array}{l}\text { a) dotze arguments a favor de la teoria que } \\
\text { la unitat de l'universal és real ( } \$ 2-17) \text {; }\end{array}$ & $\begin{array}{l}\text { a) dotze arguments a favor de la teoria que } \\
\text { la unitat de l'universal no és real ( } \$ 88 \text {-Ioo); } \\
\text { es corresponen amb els arguments que es } \\
\text { troben al punt b) de la Quaestio llatina; }\end{array}$ \\
\hline $\begin{array}{l}\text { b) dotze arguments contraris, segons els } \\
\text { quals la unitat de l'universal no és real ( } \$ \\
\text { I8-49); }\end{array}$ & $\begin{array}{l}\text { b) dues constatacions que la unitat de } \\
\text { l'universal no és real, sinó racional ( } \$ \text { IOI); } \\
\text { els arguments corresponents es troben al } \\
\text { punt c) de la Quaestio llatina; }\end{array}$ \\
\hline $\begin{array}{l}\text { c) solució de la qüestió; es constata que la } \\
\text { unitat de l'universal no és real, sinó racio- } \\
\text { nal }(\$ 50-56) \text {; }\end{array}$ & $\begin{array}{l}\text { c) tretze arguments emprats pels lògics per } \\
\text { demostrar que la unitat de l'universal és } \\
\text { real ( } \$ \text { IO5-II7); es corresponen amb els que } \\
\text { es troben al punt a) de la Quaestio llatina; }\end{array}$ \\
\hline $\begin{array}{l}\text { d) una refutació dels dotze arguments de } \\
\text { l'anterior punt a) ( } \$ 57-8 \mathrm{I}) \text {. }\end{array}$ & $\begin{array}{l}\text { d) una refutació dels tretze arguments pre- } \\
\text { cedents }(\$ \text { II8-I3I }) \text {. }\end{array}$ \\
\hline $\begin{array}{l}\text { Conclusió: si bé la natura de l'universal és } \\
\text { real, la seva unitat no ho és }(\$ 82) \text {. }\end{array}$ & $\begin{array}{l}\text { Conclusió: l'universal és u, i només exis- } \\
\text { teix en l'ànima ( } \$ \text { I32-I33). }\end{array}$ \\
\hline
\end{tabular}

Aquest fet fa pensar que existien dues redaccions de la Quaestio de Unitate Universalis de Vicent Ferrer: una de més breu, que és la que s'ha conservat en llatí, i una segona, la més completa, a la qual ara tenim accés gràcies a la traducció hebrea. En aquest cas, l'estudi de la transmissió multilingüe ha servit per retrobar, doncs, un text de Vicent Ferrer fins ara desconegut. Aquest exemple no és cap excepció. Altres casos, com ara els comentaris aristotèlics d'Averrois, mostren com dins la tradició multilingüe hebrea i llatina es poden trobar textos no conservats en l'original.

Potenciar l'estudi de la transmissió multilingüe de textos filosòfics i científics em sembla, per tant, indispensable per a poder oferir edicions fiables de les 
obres en qüestió i arribar a la comprensió del pensament autèntic de llurs autors. Aquesta feina pressuposa una col-laboració estreta entre especialistes de diferents filologies i, certament, un esforç afegit. Però és un esforç que sens dubte val la pena, tant pels resultats textuals, com també per la sensibilització envers la complexitat de les xarxes intel-lectuals al llarg de la història.

Situant-nos ja a un nivell purament textual, cal recordar que les nostres "arrels gregues" — per reprendre la famosa expressió de S. Goughenheim- es troben indestriablement unides a diferents tradicions culturals i intel-lectuals. I creure que a l'Edat Mitjana es podia llegir un text d'Aristòtil sense que intervingués en la lectura, de manera conscient o no, el ric bagatge intel-lectual àrab, és tan equivocat com pensar que avui, a l'hora d'establir els textos crítics, podem limitar-nos a la tradició suposadament "original" de l'obra, sense tenir en consideració les seves ramificacions en altres contextos culturals i lingüístics.

\section{REFERÈNCIES}

http://latintohebrew.uab.es

Ferrer, V., Quaestio de Unitate Universalis - Ma'amar Nikhbad Ba-Kolel, ed. A. Fidora i M. ZonTA, Santa Coloma de Queralt i Barcelona, 20 Io. 